\title{
La distribución del riesgo regulatorio ambiental en el derecho de las inversiones internacionales*
}

\author{
Environmental Regulatory Risk Distribution in \\ International Investment Law
}

\author{
Jorge E. Viñuales** \\ Facundo Pérez Aznar***
}

\begin{abstract}
SUMARIO: I. Introducción. II. Los poderes regulatorios del Estado. III. El impacto de los compromisos específicos. IV. La distribución del riesgo regulatorio en materia ambiental. V. Conclusión.
\end{abstract}

* Artículo recibido el 24 de noviembre de 2010 y aceptado para su publicación el 29 de junio de 2011.

** PhD (Institut d'Etudes Politiques de Paris), LLM (Harvard), DEA (HEI), es titular de la cátedra Pictet de Derecho Ambiental Internacional en el Instituto de Altos Estudios Internacionales y de Desarrollo de Ginebra (IHEID). También es Counsel en la firma Lévy Kaufmann-Kohler, en Ginebra, donde se especializa en derecho de las inversiones internacionales, así como director ejecutivo de la Sociedad Latinoamericana para el Derecho Internacional. Las opiniones expresadas en este trabajo son estrictamente personales y no reflejan aquéllas de las organizaciones a las cuales el autor está afiliado.

*** Doctorando (IHEID), DEA (HEI), es asistente de enseñanza de la Unidad de Derecho Internacional del IHEID y se desempeñó como abogado en la Dirección Nacional de Asuntos y Controversias Internacionales de la Procuración del Tesoro de la República Argentina. Las opiniones expresadas en este trabajo son estrictamente personales y no reflejan aquéllas de las organizaciones a las cuales el autor está afiliado. 
RESUMEN: El objeto del presente estudio son los distintos métodos jurídicos que pueden ser empleados por los tribunales arbitrales a fin de distribuir el riesgo regulatorio en materia ambiental entre inversionistas extranjeros y Estados receptores. Más precisamente, el análisis de dichos métodos busca elucidar, por una parte, el margen que detentan los Estados, en el marco de sus poderes regulatorios, para adoptar reglamentaciones ambientales así como, por otra parte, el riesgo regulatorio en que incurren los inversionistas extranjeros cuyas actividades se encuentran (particularmente) expuestas a tales reglamentaciones. Como se verá, el método principal que permite sopesar dichos intereses a la luz de las circunstancias de cada caso es la doctrina de los poderes de policía del Estado. Sin embargo, la aplicación de esta doctrina plantea dificultades importantes cuando el Estado receptor ha asumido compromisos específicos en materia regulatoria con respecto a las actividades de los inversionistas extranjeros. Palabras clave: riesgo regulatorio, reglamentación ambiental, inversiones extranjeras, doctrina de los poderes de policía, compromisos específicos

ABSTRACT: This study focuses on the different legal tools that can be used by arbitral tribunals in order to distribute between foreign investors and host States the risks arising from environmental regulation. More specifically, the analysis of these tools aims at clarifying, on the one hand, the host States' room for maneuver in the adoption of environmental regulations and, on the other hand, the regulatory risk undergone by foreign investors whose activities are particularly exposed to such regulations. As this study shows, the main tool used to balance these different interests, in the lights of the circumstances of each case, is the police powers doctrine. However, the aplication of this doctrine raises some difficulties in those cases where the host State has given specific assurances regarding the regulation of the activities of foreign investors.

Descriptors: regulatory risk, environmental regulation, foreign investment, police powers doctrine, specific assurances.

RÉSUMÉ: L'objectif de cette étude est l'analyse des différentes méthodes juridiques qui peuvent être utilisés par les tribunaux arbitraux dans le but de distribuer les risques régulateurs pour l'environnement entre les investisseurs étrangers et des pays d'accueil. Plus précisément, l'analyse de ces méthodes cherche à élucider, d'une part, la marge d'appréciation des États dans le cadre de ses pouvoirs de réglementation, d'adopter des règlements sur l'environnement et, d'autre part, le risque régulateur encourus par les investisseurs étrangers dont activités sont (notamment) exposés à de tels règlements. Comme on le verra, la méthode principale qui permet un équilibre entre ces intérêts à la lumière des circonstances de chaque cas est la doctrine des pouvoirs de police de l'Etat. Toutefois, l'application de cette doctrine pose des difficultés majeures lorsque l'Etat d'accueil a pris des engagements spécifiques en matière de réglementation en ce qui concerne les activités des investisseurs étrangers.

Mots-Clés: Risque Régulateurs, La Réglementation Environnementale, Les Investissements Étrangers, La Doctrine des Pouvoirs de Police, Assurances Spécifiques. 


\section{INTRODUCCIÓN}

La multiplicación de los arbitrajes relativos a litigios entre Estados e inversionistas extranjeros (arbitrajes de inversión) durante la última década es uno de los fenómenos más remarcables en lo que respecta a la aplicación práctica del derecho internacional. Dicho fenómeno ha coincidido, en parte, con otra tendencia de extrema importancia, a saber, el desarrollo del derecho ambiental internacional. A medida en que la reglamentación estatal de cuestiones ambientales se ha vuelto más importante y precisa, el marco jurídico en que operan los inversionistas extranjeros se ha ido transformando, en ciertos casos de modo perjudicial para las operaciones de dichos inversionistas. Ello explica que un número creciente de arbitrajes de inversión involucren cuestiones ambientales, y que los tribunales arbitrales a cargo de la resolución de dichos litigios se vean confrontados a la necesidad de sopesar diversos intereses en juego, entre los cuales se encuentran la protección del medio ambiente y los intereses económicos de los inversionistas extranjeros (e indirectamente también del Estado receptor de la inversión).

En este contexto, el objeto del presente estudio son los distintos métodos jurídicos que pueden ser empleados por los tribunales arbitrales a fin de distribuir el riesgo regulatorio en materia ambiental entre inversionistas extranjeros y Estados receptores. Más precisamente, el análisis de dichos métodos busca elucidar, por una parte, el margen que detentan los Estados, en el marco de sus poderes regulatorios, para adoptar reglamentaciones ambientales así como, por otra parte, el riesgo regulatorio en que incurren los inversionistas extranjeros cuyas actividades se encuentran (particularmente) expuestas a tales reglamentaciones. Como se verá, el método principal que permite sopesar dichos intereses a la luz de las circunstancias de cada caso es la doctrina de los poderes de policía del Estado; sin embargo, la aplicación de esta doctrina plantea dificultades importantes cuando el Estado receptor ha asumido compromisos específicos en materia regulatoria con respecto a las actividades de los inversionistas extranjeros. En dicho caso debe determinarse cuál es el efecto jurídico de estos compromisos o garantías brindadas al inversionista. A modo de soluciones posibles, proponemos 
tres modos de sopesar los diversos intereses en juego, a través (i) del análisis del carácter razonable/legítimo de las expectativas del inversionista, (ii) de su contribución al daño, y (iii) de una teoría de los intereses protegidos, respectivamente.

El análisis se desarrolla en tres partes. En la primera parte abordamos la cuestión del poder regulatorio del Estado y de sus manifestaciones a la luz de la jurisprudencia arbitral. La segunda parte trata de la cuestión de los compromisos específicos asumidos por el Estado receptor de la inversión, en particular en materia de reglamentación ambiental. Por último, la tercera parte analiza tres modos en que la distribución del riesgo ambiental puede ser efectuada a nivel jurídico.

\section{LOS PODERES REGULATORIOS DEL ESTADO}

\section{Concepto general y aplicaciones}

La referencia a los poderes regulatorios del Estado ha surgido en los últimos años como una de las técnicas más importantes para resolver los conflictos entre normas de protección de inversiones y medidas tendientes a la protección de la salud pública, el medio ambiente, y el respeto de los derechos humanos. Es difícil determinar con precisión el alcance del concepto jurídico de poderes regulatorios del Estado, ya que se trata de una manifestación general de la dimensión interna de la soberanía del Estado, concepto en sí mismo muy amplio. ${ }^{1}$ A menudo, la doctrina y la jurisprudencia han tratado de circunscribir dicha doctrina sir-

1 Caso de la Isla de Palmas (Holanda v. Estados Unidos), 4 de abril de 1928, Reports of International Arbitral Awards, vol. II pp. 829-871, en la p. 838 y 839. Véase también Virally, M., "Une pierre d'angle qui résiste au temps: avatars et pérennité de l'idée de souveraineté", en I.U.H.E.I., Les relations internationales dans un monde en mutation, Leyden, Sitjhoff, 1979, pp. 179-195 ; Annan, R. P., "Sovereign Equality of States in International Law”, RCADI, t. 197, 1986, pp. 9-228, Schachter, O., "Sovereignty - Then and Now", en Macdonald, R. St. John (ed.), Essays in Honour of Wang Tieya, 1993, capítulo 45; Barberis, J. A., "Les liens juridiques entre l'Etat et son territoire : perspectives théoriques et évolution du droit international”, Annuaire français de droit international, 1999, 45, 132; Barberis, J. A., El territorio del Estado y la soberanía territorial, Buenos Aires, Editorial Abaco de Rodolfo Depalma, 2003. 
viéndose de formulaciones o conceptos jurídicos más específicos, como la doctrina de los poderes de policía, la doctrina del margen de apreciación o las cláusulas de necesidad y urgencia. ${ }^{2}$ Nuestro análisis se centrará en la doctrina de los poderes de policía y su empleo como herramienta jurídica para sopesar consideraciones ambientales e intereses de inversionistas extranjeros; sin embargo, nos parece útil introducir ciertas observaciones básicas en relación con los otros dos conceptos mencionados, con el fin de poder distinguirlos de la doctrina de los poderes de policía.

La denominada doctrina del margen de apreciación es esencialmente un estándar de deferencia que ciertas jurisdicciones internacionales acuerdan a las decisiones de las autoridades nacionales debido a la mejor posición que éstas tienen para apreciar las particularidades de una situación dada. ${ }^{3}$ Esto es particularmente importante en las controversias relativas al medio ambiente en donde una agencia reguladora especializada en la protección de la salud o del medio ambiente toma medidas que posteriormente son impugnadas por el inversionista por considerarlas contrarias a las normas internacionales de protección de inver-

2 Véase Viñuales, J. E., "Foreign Investment and the Environment in International Law: An Ambiguous Relationship”, (2010) British Yearbook of International Law 80, 2009, 244, pp. 309-324.

3 Dicha doctrina fue desarrollada inicialmente por el Tribunal Europeo de Derechos Humanos, con base en la práctica de ciertas jurisdicciones europeas de tradición civilista, y adoptada posteriormente por otros órganos, principalmente en el ámbito de la protección de los derechos humanos. En el caso Handyside c. Reino Unido, el Tribunal afirmó lo siguiente: "[N]o es posible encontrar en el derecho interno de los distintos Estados en forma constante una concepción europea uniforme de la moral. La postura adoptada por sus respectivas legislaciones respecto de los requisitos de la moral varía de en el tiempo y de un lugar a otro, especialmente en nuestra época que se caracteriza por una evolución rápida y de gran alcance de opiniones sobre el tema. Por razón de su contacto directo y contínuo con las fuerzas vivas de sus países, las autoridades estatales, en principio, se encuentran en una mejor posición que el juez internacional para dar una opinión sobre el contenido exacto de estos requisitos, así como en la "necesidad" de una "restricción" o "pena" destinados a su encuentro... Este margen se da tanto para el legislador nacional ("prescripto por la ley”) como para los órganos, judicial, entre otros, que están llamados a interpretar y aplicar las leyes en vigor”, Handyside c. Reino Unido, CEDH, sentencia del 7 de diciembre de 1976, A 24, párrafo 48. Véase Y. Arai-Takahashi, The Margin of Appreciation Doctrine and the Principle of Proportionality in the Jurisprudence of the ECHR, Intersentia, Antwerp, 2002; Hutchinson, M., "The Margin of Appreciation Doctrine in the European Court of Human Rights", 48 International and Comparative Law Quarterly 638, 1999. 
siones. ${ }^{4}$ Como se verá posteriormente, cuando abordemos en detalle la doctrina de los poderes de policía, la diferencia entre ésta y la doctrina del margen de apreciación es sutil pero suficientemente perceptible. En el ámbito de los litigios de inversión, ${ }^{5}$ la diferencia más significativa es que si un tribunal arbitral concluye que cierta medida se encuentra protegida por la doctrina de los poderes de policía, el resultado será que dicha medida no infringe las normas de protección de los inversionistas, mientras que la deferencia acordada por un tribunal arbitral a las apreciaciones científicas de un ente regulador nacional, en virtud de la doctrina del margen de apreciación, sólo constituye una constatación de hecho que, técnicamente, puede o no dar lugar a responsabilidad. Por ejemplo, en Tecmed c. México, ${ }^{6}$ el tribunal analizó la negativa de las autoridades locales de renovar una licencia para la explotación de un vertedero de desechos a la luz tanto de las doctrinas de los poderes de la policía como del margen de apreciación. El tribunal desestimó la aplicación de la primera ${ }^{7}$ pero retuvo el test de proporcionalidad de la segunda, lo que no le impidió constatar una violación de la cláusula de expropiación del tratado aplicable. ${ }^{8}$

Otra expresión de los poderes regulatorios del Estado son las cláusulas de emergencia incluidas en ciertos TBI's (en particular, el artícu-

4 Véase, en materia de arbitraje de inversión: S.D. Myers v. Canadá, TLCAN (CNUDMI) Primer laudo parcial, Arbitraje bajo las reglas de la CNUDMI, 13 de noviembre de 2000 ('S.D. Myers v. Canada'), párr. 263; Methanex Corporation c. Estados Unidos de América, TLCAN (CNUDMI), Laudo del 3 de agosto 2005, parte III, ch. A, párr. 101; Glamis Gold c. Estados Unidos, supra note 36, párr. 779; Chemtura Corporation (antes Crompton Corporation) c. el Gobierno de Canadá, TLCAN (CNUDMI), Laudo, 2 de agosto de 2010 (“Chemtura c. el Canadá”), párrs. 133-134.

5 En el marco del Tribunal Europeo de Derechos Humanos, la doctrina sirve para fines mucho más amplios, incluyendo la adaptación de las normas del Convenio Europeo de las especificidades culturales y políticas de cada Estado parte en la Convenio.

6 Técnicas Medioambientales Tecmed SA c. Estados Unidos Mexicanos, Caso CIADI núm. ARB (AF) / 00 / 2, Laudo del 29 de mayo de 2003 (“Tecmed c. México").

7 Ibidem, párr. 119.

8 Ibidem, párr. 121, refiriéndose a la controvertida conclusión en Compañía del Desarrollo de Santa Elena SA v. República de Costa Rica, Caso CIADI núm. ARB/96/1, Laudo, 17 de febre-ro de 2000 (“CDSE v. Costa Rica”). 
lo XI del TBI Argentina-Estados Unidos ${ }^{9}$ ) y la norma consuetudinaria relativa al estado de necesidad codificada en el artículo 25 del Proyecto de la Comisión de Derecho Internacional sobre la Responsabilidad del Estado. ${ }^{10}$ La aplicación potencial de dicha causal para la protección de los intereses ambientales fue reconocida por primera vez en el caso Gabčíkovo-Nagymaros, ante la Corte Internacional de Justicia. ${ }^{11}$ Ciertas cláusulas de emergencia pública (así como la norma relativa al estado de necesidad) han sido invocadas en el contexto de la serie de litigios de inversión relacionados con la crisis argentina de 2001-2003. ${ }^{12}$ En dos

9 Véase Treaty between the Estados Unidos of America and the Argentine Republic concerning the Reciprocal Encouragement and Protection of Investment, 14 de noviembre de 1991, 31 ILM 124 ('TBI Argentina-EEUU'). La versión en español se encuentra disponible en http://infoleg.mecon.gov.ar/infolegInternet/resaltaranexos/0-4999/523/norma.htm. El artículo XI de este tratado dispone lo siguiente: "El presente Tratado no impedirá la aplicación por cualquiera de las Partes de las medidas necesarias para el mantenimiento del orden público, el cumplimiento de sus obligaciones para el mantenimiento o la restauración de la paz o seguridad internacionales, o la protección de sus propios intereses esenciales de seguridad".

10 Responsabilidad de los Estados por Hechos Ilícitos Internacionales, G.A. Res. A.G 56/83, U.N. Doc A/RES/56/83, 12 de diciembre de 2001 ('Artículos de la CDI), art. 25.

11 Véase: Projecto Gabč́kovo-Nagymaros Project (Hungría/Eslovakia), CIJ Recueil 1997, 7 ('Gabčíkovo-Nagymaros'), párr. 53, caso en el cual la Corte reconoció expresamente: "Las preocupaciones expresadas por Hungría por su entorno natural en la región afectada por el Proyecto Gabč́kovo-Nagymaros relacionado con un "interés esencial” de ese Estado, en el sentido dado a esa expresión en el artículo 33 del Proyecto de la Comisión de Derecho Internacional.”

12 Véase: CMS c. Argentina-, CMS Gas Transmission Company c. República Argentina, Caso núm. ARB/01/08 CIADI, decisión sobre la anulación, el 25 de septiembre de 2007 (“CMS c. Argentina Anulación”); LG \& E c. República Argentina, Caso CIADI núm. ARB/02/1, Decisión sobre la responsabilidad de 13 de octubre de 2006 ("LG\&E-Responsabilidad"), Laudo de 25 de julio de 2007 (“LG\&E-Laudo”); Enron y Ponderosa Assets c. República Argentina, Caso CIADI núm. ARB/ 01 / 3, Laudo del 22 mayo de 2007 (“Enron c.Argentina-Laudo”), Decisión sobre Anulación, de 30 de julio de 2010 (“Enron c.Argentina-Anulación”); Sempra Energy c. República Argentina, Caso CIADI núm. ARB/02/16, laudo de 28 de septiembre de 2007 ("Sempra c. Argentina-Laudo"), Decisión sobre Anulación, de 29 de junio de 2010 (“Sempra c.Argentina-Anulación”); Metalpar c. República Argentina, Caso CIADI núm. ARB/03/5, Laudo de 6 de junio de 2008 ("Metalpar c. Argentina”); Continental Casualty c. República Argentina, Caso CIADI núm. ARB/03/9, Laudo de 5 de septiembre de 2008 (“Continental Casualty c. Argentina”); Suez, Sociedad General de Aguas de Barcelona S.A. e InterAguas Servicios Integrales del Agua S.A. c. República Argentina, Caso CIADI núm. ARB/03/17 ('Suez c. Argentina-03/17’), Decisión sobre responsabilidad, 30 de julio de 2010; Suez, Sociedad General de Aguas de Barcelona, S.A. y Vivendi Universal, S.A. c. República Argentina, Caso CIADI núm. ARB/03/19 (Suez c. Argentina-03/19'), Decisión sobre responsabilidad, 30 de julio de 2010; AWG Group Ltd. c. República Argentina (CNUDMI), 
de estos casos, ${ }^{13}$ los tribunales consideraron que las medidas adoptadas por Argentina se encontraban justificadas, parcialmente, por la situación de emergencia. Ambos tribunales basaron su decision en el artículo XI del TBI Argentina-Estados Unidos. ${ }^{14} \mathrm{~A}$ esto debe agregarse la anulación, a mediados de 2010, de dos laudos que habían rechazado, en el marco de la crisis argentina, la aplicación de las cláusulas de emergencia y de estado de necesidad. ${ }^{15}$ El efecto de dichas cláusulas ha sido debatido por la doctrina y la jurisprudencia. Más allá de ciertas sutilezas doctrinales acerca de la naturaleza jurídica del estado de necesidad (ya sea como causal de exclusión de la ilicitud de un acto o como mera justificación $^{16}$ ), se considera que la aplicación de dichas cláusulas constituye un límite a la responsabilidad internacional del Estado. Por consiguiente, no se trata sólo de una apreciación de hecho, como en el marco de la doctrina del margen de apreciación, sino de una cuestión de delimitación de la responsabilidad del Estado, como en el caso de la doctrina de los poderes de policía. Existe sin embargo una diferencia significativa entre esta última y las cláusulas de emergencia y de estado de necesidad. Mientras que el poder regulatorio del Estado (como corolario de su soberanía) erige la primera en excepción implícita a la responsabilidad del Estado, las cláusulas de emergencia pública sólo pueden ser invocadas si han sido previstas en el tratado aplicable. En lo que respecta al estado de necesidad, a pesar de su carácter consuetudinario y por ende general, su admisión como límite de la responsabilidad del Estado se encuentra sujeta a requisitos mucho más rigurosos que aquéllos que rigen la aplicación de la doctrina de los poderes de policía.

Decisión sobre responsabilidad, 30 de julio de 2010. A este respecto véase: Viñuales, J. E., "State of Necessity and Peremptory Norms in International Investment Law", (2008) 14 NAFTA: Law and Business Review of the Americas 79; Reinisch, A., "Necessity in International Investment Arbitration: An Unnecessary Split of Opinions in Recent CIADI Cases?”, 8 Journal of World Investment \& Trade, 2007, 191.

13 LG\&E-Responsabilidad; Continental Casualty c. Argentina, supra nota 12.

14 Véase: LG\&E-Responsabilidad, párr. 234-237; Continental Casualty c. Argentina, párr. 162, supra nota 12 .

15 Enron c.Argentina-Anulación; Sempra c. Argentina-Anulación, supra nota 12.

16 Véase Lowe, V., "Precluding Wrongfulness or Responsibility: A Plea for Excuses”, (1999) 10 European Journal of International Law 405. Dicha distinción podría tener consecuencias en materia de indemnización. 
En resumen, las particularidades (su carácter menos excepcional y su efecto) que permiten diferenciar la doctrina de los poderes de policía de otros conceptos jurídicos susceptibles de expresar el poder regulatorio del Estado (doctrina del margen de apreciación y cláusulas de emergencia y de estado de necesidad) explican, en parte, la razón por la cual la primera ha sido utilizada más frecuentemente como herramienta para sopesar consideraciones ambientales e intereses de los inversionistas extranjeros. Dichas particularidades serán analizadas con más detalle a continuación.

\section{La doctrina de los poderes de policía}

La doctrina de los poderes de policía tal como se aplica en el derecho internacional de las inversiones parece haberse desarrollado a partir de dos fuentes principales, una que tiene sus raíces en la doctrina y la práctica norteamericana ${ }^{17}$ y la otra en el derecho internacional general. ${ }^{18}$ En ambos casos, dicha doctrina fue debatida y aplicada ante todo

17 Acerca de los orígenes de esta doctrina en Estados Unidos, véase Friedman, S., Expropriation in International Law, Londres, Stevens, 1953, 51; American Law Institute (ALI), Restatement (Second) of the Law of Foreign Relations of the United States, 1965, artículo 197(1)(a); ALI, Restatement (Third) of the Law of Foreign Relations of the United States, 1986, artículo 712, comentario, letra (g), según el cual: "[a] State is not responsible for loss of property or for other economic disadvantage resulting from bona fide general taxation, regulation, forfeiture for crime, or other action of the kind that is commonly accepted as within the police power of states, if it is not discriminatory... and is not designed to cause the alien to abandon the property to the state or sell it at a distress price. As under United States constitutional law, the line between 'taking' and 'regulation' is sometimes uncertain”; Sohn, L. B. y Baxter, R. R., "Draft Convention on the International Legal Responsibility of States for Injuries to Aliens", 55 American Journal of International Law 545 (Harvard Draft 1961), 1961, artículo 10(5). Esta fuente ha influenciado la práctica delTribunal de reclamaciones Irán-Estados Unidos así como la de los tribunales arbitrales constituidos bajo el capítulo once del TLCAN. Véase Aldrich, G. H., "What Constitutes a Compensable Taking of Property? The Decisions of the Iran-United States Claims Tribunal”, (1994) 88 American Journal of International Law 585; Kinnear, M. et al., Investment Disputes under NAFTA. An Annotated Guide to NAFTA Chapter 11 (Kluwer Law International, La Haya, 2006), comentario al artículo 1110, 49-55. Véase también el caso Fireman's Fund Insurance Company c. México, Caso CIADI No. ARB(AF)/02/1, Laudo, 14 de julio de 2006, párr. 176(j).

18 Véase Friedman, S., Expropriation in International Law, supra nota 17, quien observa lo siguiente en las páginas 50-51 de su estudio: "[s]tate practice contains numerous examples 
en relación con la cuestión de expropiaciones no sujetas a indemnización; sin embargo, su efecto no es el de excluir la indemnización, sino, como lo hemos mencionado anteriormente, el de excluir la calificación de expropiación.

En los últimos años, la doctrina de los poderes de policía ha influenciado la redacción de ciertos tratados modelo de protección de inversiones ${ }^{19} \mathrm{y}$, como lo hemos anticipado, también ha sido analizada y aplicada en el contexto específico de medidas ambientales perjudiciales para los intereses de inversionistas extranjeros. Uno de los primeros casos en que se planteó la cuestión es S.D. Myers c. Canadá. ${ }^{20}$ En dicho caso el tribunal debía determinar la conformidad con respecto al TLCAN de ciertas medidas administrativas adoptadas por el gobierno canadiense por las cuales se prohibía la exportación de residuos tóxicos desde Canadá hacia los Estados Unidos. El tribunal mencionó lo siguiente, en relación con la distinción entre expropiación y reglamentación:

of the suppression of particular activities which may be carried out for two reasons. In the first place, the activity may be regarded as harmful at a given time although it was perfectly legal hitherto and may indeed become so again. Secondly, it may be desired for administrative or fiscal reasons to prevent the exercise of a profitable activity by private individuals and to place it in the hands of the State in the form of a monopoly... measures were adopted in France and these were sometimes justified by consideration of hygiene and public health or by the need for a more efficient working of public services, as in the case of the prohibition of the manufacture of white lead (Law of July 20, 1909) or the abolition of private telegraphic undertakings in $1837 \ldots$ In all these cases where a particular activity was suppressed, with a resulting destruction of important corporeal and incorporeal property rights, no compensation was paid to those suffering damage in consequence of the measures taken"; Christie, G. C., 'What Constitutes a Taking of Property Under International Law', (1962) 38 British Yearbook of International Law 307 ss.; I Brownlie, Principles of Public International Law, Oxford, Oxford University Press, 2008, 536, según el cual: “[j]urists supporting the compensation rule recognize the existence of exceptions, the most widely accepted of which are as follows: under treaty provisions; as a legitimate exercise of police power, including measures of defence against external threats; confiscation as a penalty for crimes; seizure by way of taxation or other fiscal measures; loss caused indirectly by health and planning legislation and the concomitant restrictions on the use of property..."; A Newcombe, 'The Boundaries of Regulatory Expropriation in International Law', 20 ICSID Review. Foreign Investment Law Journal 1, 2005.

19 Véase, por ejemplo: TBI Modelo de EEUU de 2004, Anexo B; TBI Modelo de Canadá de 2004, Anexo B 13(1).

20 S.D. Myers c. Canadá, supra nota 4. 
El conjunto de precedentes no trata a las acciones regulatorias como el equivalente a una expropiación. La conducta regulatoria de los poderes públicos es poco probable que sea objeto de un reclamo legítimo conforme al Artículo 1110 [sobre expropiación] del TLCAN, aunque el Tribunal no descarta esa posibilidad... Las expropiaciones suelen implicar la privación de los derechos de propiedad; las medidas regulatorias, una interferencia menor. La distinción entre la expropiación y la regulación descarta la mayoría de los posibles casos de reclamos relativos a la intervención económica de un Estado y reduce el riesgo de que los gobiernos estén sujetos a las reclamaciones sobre la marcha de sus medidas de gestión de los asuntos públicos. ${ }^{21}$

En un caso posterior que ya ha sido mencionado, Methanex c. Estados Unidos, ${ }^{22}$ esta distinción fue confirmada y matizada. El inversionista alegaba que había sido víctima de una expropiación regulatoria como consecuencia de una medida adoptada por las autoridades de California que prohibía la utilización de un aditivo para combustible _el EMTB_- a causa de su potencial de contaminación de acuíferos. Methanex no era un productor de EMTB, sino de una materia prima, el metanol, utilizado en la producción de dicho aditivo. El tribunal rechazó la demanda considerando inter alia que las medidas adoptadas por el gobierno californiano constituían un ejercicio de los poderes de policía del Estado:

[C]omo cuestión de derecho internacional general, una reglamentación no discriminatoria con un fin público, que se dicta de conformidad con el debido proceso y que afecta, inter alios, a un inversionista extranjero o a una inversión no se considera expropiatoria e indemnizable a menos que se hayan asumido compromisos específicos por el gobierno regulador en relación con el inversionista extranjero, que en aquel entonces contemplaba una inversión, que el gobierno se abstendría de dicha regulación. ${ }^{23}$

La posición adoptada por el tribunal en Methanex c. Estados Unidos fue confirmada, subsiguientemente, en el caso Saluka c. República Checa, en

21 Ibidem, párrs. 281-282 (nuestra traducción del original en inglés).

22 Methanex v. Estados Unidos, supra nota 4.

23 Ibidem, párr. 7 (nuestra traducción del original en inglés). 
el cual el tribunal consideró, citando el caso Methanex como precedente, que:

[E]l principio de que un Estado no realizó una expropiación, y por lo tanto no está obligado a pagar una indemnización a un inversionista extranjero desposeído, cuando adopta normas generales que son "comúnmente aceptadas como dentro de los poderes de policía de los Estados" forma parte del derecho consuetudinario en la actualidad. ${ }^{24}$

A su vez, el caso Saluka sirvió de base al razonamiento del tribunal en el caso Chemtura c. Canadá, el cual proporciona, por el momento, la más clara formulación de la doctrina de los poderes de policía en materia de reglamentación ambiental:

[E]l Tribunal considera, en todo caso, que las medidas impugnadas por la demandante constituyen un ejercicio válido de los poderes de policía de la demandada. Como se comentó en detalle en relación con el artículo 1105 del TLCAN, el PMRA [ente regulador canadiense] tomó medidas dentro de su mandato, de manera no discriminatoria, motivado por la creciente conciencia de los peligros presentados por el lindano para la salud humana y el medio ambiente. Las medidas adoptadas en tales circunstancias constituyen un ejercicio válido de los poderes de policía del Estado y, en consecuencia, no constituyen una expropiación. ${ }^{25}$

La posición del tribunal en el caso Chemtura c. Canada no deja dudas en cuanto a los efectos de la doctrina de los poderes de policía. Aquellas medidas ambientales que respeten ciertas condiciones (que no sean ultra vires, que persigan un objetivo de bien público y que no sean discriminatorias) no serán consideradas como una violación de la cláusula de expropiación de un TBI a menos que el Estado receptor haya asumido compromisos específicos con respecto al inversionista perjudicado. Dicha excepción, mencionada expresamente en el caso Methanex c. Estados Unidos, puede plantear dificultades importantes en la práctica, por lo

24 Saluka Investments B.V. c. República Checa, UNCITRAL, Laudo Parcial, 17 de marzo de 2006 ('Saluka c. República Checa'), párr. 262. (nuestra traducción del original en inglés).

25 Chemtura v. Canadá, supra nota 4, párr. 266, en el que se cita el párrafo 262 del laudo en el caso Saluka c. República Checa, supra nota 24 (nuestra traducción del original en inglés). 
que nos parece importante profundizar la cuestión de su alcance jurídico.

\section{EL IMPACTO DE LOS COMPROMISOS ESPECÍFICOS}

\section{Expectativas legítimas y compromisos específicos}

El concepto de compromisos específicos (o "garantías específicas") ha sido utilizado frecuentemente en litigios de inversión, tanto para el análisis de la existencia de una expropiación ${ }^{26}$ o de una violación del estándar de trato justo y equitativo, ${ }^{27}$ como también para analizar otros estándares previstos en los tratados bilaterales de inversión. ${ }^{28}$ El concepto ha sido empleado particularmente en relación con la existencia de expectativas legítimas por parte de los inversionistas. En la presente sección, nuestro objetivo es introducir ciertas precisiones con respecto a la relación entre los conceptos de "expectativas legítimas" y de "compromisos específicos", respectivamente.

Ciertos tratados bilaterales de inversión incluyen una referencia expresa a uno de estos conceptos, sin que la diferencia entre ellos resulte clara. Por ejemplo, la disposición del TBI celebrado entre Chipre y la Unión Económica Belgo-Luxemburguesa en 1991 sobre "Privación y limitación de la propiedad" prevé lo siguiente:

1. Cada Parte Contratante se compromete a no adoptar ninguna medida de expropiación ni nacionalización ni cualquier otra medida que tenga el efecto, directa

26 Methanex c. Estados Unidos, supra nota 4, parte IV capítulo D (3), párr. 7; Compañía de Aguas del Aconquija SA and Vivendi Universal SA v Argentina, Award, ICSID Case No ARB/97/3, IIC 307 (2007) 20 August 2007, párr. 7.5.21.

27 Véase, entre otros, CMS c. Argentina, Laudo, supra nota 12, párr. 277; International Thunderbird Gaming Corporation v Mexico, Laudo, Ad hoc-UNCITRAL Arbitration Rules, 26 de enero de 2006 ("Thunderbird c México"), párr. 44; Glamis Gold c. Estados Unidos, supra note 36, párr. 800-801 Suez c. Argentina-03/17, supra nota 12, párr. 214; Plama Consortium Ltd c. Bulgaria, Laudo, Caso CIADI No ARB/03/24, 27 de agosto de 2008, párr. 177; EDF (Services) Ltd v Romania, Laudo, Caso CIADI No ARB/05/13, 2 de octubre de 2009, párr. 298.

28 Véase por ejemplo AES Summit Generation Limited y AES-Tisza Erömü Kft c. Hungría, Laudo, Caso CIADI No. ARB/07/22, 17 de septiembre de 2010, párrafo 10.3.35. 
o indirectamente, de privar a los inversionistas de la otra Parte Contratante de sus inversiones en su territorio.

2. Si por razones de utilidad púbica. necesidad, seguridad o interés nacional se requiriese de una derogación de lo estipulado en el párrafo $1^{\circ}$, se deberán cumplir las siguientes condiciones:

a) Se tomarán las medidas conforme al debido proceso legal;

b) Las medidas no serán discriminatorias, ni contrarias a ningún compromiso específico;

c) Las medidas estarán acompañadas de estipulaciones para el pago de una compensación pronta, adecuada y efectiva. ${ }^{29}$

El TBI Modelo de los Estados Unidos menciona a las "expectativas" de los inversionistas en su cláusula de expropiación. El Anexo B titulado "Expropiación" establece que:

la determinación... de una expropiación indirecta, requiere una investigación caso por caso, basada en los hechos, que considere, entre otros factores... la me-

29 Artículo 4o., TBI Chipre/Unión Económica Belgo-Luxemburguesa de 1991 (nuestra traducción del original en inglés) (énfasis añadido). Otros tratados celebrados por Belgica y Luxemburgo contienen disposiciones similares: TBI Gergia/Unión Económica BélgoLuxemburguesa de 1993, TBI Letonia/Unión Económica Bélgo-Luxemburguesa de 1996, TBI Estonia/Unión Económica Bélgo-Luxemburguesa de 1996, TBI Ucrania/Unión Económica Bélgo-Luxemburguesa de 1996, TBI Lituania/Unión Económica Bélgo-Luxemburguesa de 1997, TBI Kazajstán/Unión Económica Bélgo-Luxemburguesa de 1998, ITBI Uzbekistán/ Unión Económica Bélgo-Luxemburguesa de 1998, TBI Macedonia/Unión Económica BélgoLuxemburguesa de 1999, TBI Líbano/Unión Económica Bélgo-Luxemburguesa de 1999, TBI Albania/Unión Económica Bélgo-Luxemburguesa de 1999, TBI Armenia/Unión Económica Bélgo-Luxemburguesa de 200, TBI Zambia/Unión Económica Bélgo-Luxemburguesa de 2001, TBI Yemen/Unión Económica Bélgo-Luxemburguesa de 2000, TBI Belarús/ Unión Económica Bélgo-Luxemburguesa de 2002, TBI Jamahiriya Árabe Libia/Unión Económica Bélgo-Luxemburguesa de 2004, TBI Bosnia y Herzegovina/Unión Económica Bélgo-Luxemburguesa de 2004, TBI Azerbaiyán/Unión Económica Bélgo-Luxemburguesa de de 2004, TBI Sudán/Unión Económica Bélgo-Luxemburguesa de 2005, TBI Perú/ Unión Económica Bélgo-Luxemburguesa de 2005, TBI Mauricio/Unión Económica BélgoLuxemburguesa de 2005, TBI Guatemala/Unión Económica Bélgo-Luxemburguesa de 2005, TBI Etiopía/Unión Económica Bélgo-Luxemburguesa de 2006. Disponibles en http: / /www. unctadxi.org/templates/docsearch 779. aspx. 
dida en la cual la acción del gobierno interfiere con expectativas inequívocas y razonables en la inversión. ${ }^{30}$

En forma similar, el TBI modelo canadiense de 2004 menciona expresamente el criterio que "la medida o serie de medidas interfiera con expectativas definidas y razonables apoyadas en la inversión” como uno de los factores que deben orientar a los tribunales arbitrales en "[l]a determinación de si una medida o serie de medidas de una Parte constituye una expropiación indirecta...”.31

De modo básico, puede afirmarse que una diferencia relativamente nítida entre los conceptos de "expectativa legítima" y "compromiso específico" consiste en que el primer concepto describe la situación del inversionista mientras que el segundo concepto se refiere a una promesa efectuada por el Estado receptor. Desde otro ángulo, también podría afirmarse que para que un inversionista pueda establecer la existencia de una expectativa legítima es necesario que el Estado receptor haya asumido un compromiso específico con respecto al inversionista; sin embargo, si se entra en detalle, la relación entre ambos conceptos es mucho más compleja, ya que la existencia de una expectativa legítima no supone necesariamente que el Estado receptor haya asumido un compromiso específico, a menos que este último concepto sea definido de modo muy amplio.

La jurisprudencia se ha enfrentado a todas las ambigüedades planteadas por esta cuestión en varios casos, dando lugar a ciertas divergencias entre las conclusiones de los diversos tribunales. Por ejemplo, en el caso Thunderbid c. México el tribunal delimitó los compromisos específicos dentro del concepto de expectativas legítimas de la siguiente manera:

A la luz de jurisprudencia reciente sobre inversiones y del principio de buena fe del derecho internacional consuetudinario, el concepto de "expectativas legítimas" guarda relación, en el contexto del TLCAN, con una situación en que la conducta de la Parte Contratante crea expectativas razonables y justificables para que un inversionista (o

30 Anexo B, artículo 4o. del TBI Modelo EEUU de 2004 (nuestra traducción del original en inglés)

31 Anexo B 13(1)(b) respecto de la aclaración sobre expropiación indirecta, TBI Model de Canadá de 2004 (nuestra traducción del original en inglés) 
una inversión) actúe basándose en esa conducta, por lo cual el hecho de que una Parte del TLCAN no cumpla esas expectativas puede causar perjuicios al inversionista (o a la inversión). ${ }^{32}$

A pesar de esta afirmación el tribunal consideró que las expectativas legítimas de la parte demandante no tenían fundamento ya que ésta "sabía, cuando decidió invertir en actividades de juego en México, que los juegos de azar y apuesta constituyen una actividad ilegal conforme a la legislación mexicana". ${ }^{33}$ El tribunal consideró que "no p[odía] basarse en presunciones o inferencias, mucho menos especulaciones, respecto a los antecedentes" ${ }^{34}$ para determinar la existencia de expectativas legítimas para presentar reclamaciones en los términos de lo dispuesto por los artículos 1102, 1105 y/o 1110 del TLCAN. ${ }^{35}$

Por el contrario, algunos de los tribunales que se pronunciaron sobre las consecuencias de la crisis argentina de 2001-2003 parecen haber adoptado una visión más amplia de la relación entre compromisos específicos y expectativas legítimas. Por ejemplo, el tribunal en $L G \& E$ c. Argentina consideró que Argentina había violado el TBI aplicable por no cumplir con su propia legislación en el sector de transporte de gas. ${ }^{36}$ Para llegar a esta conclusión, el tribunal se basó únicamente en disposiciones del marco legal general, que son aplicables a todos los actores del sistema de distribución y transporte de gas en Argentina y no en compromisos específicos otorgados a la parte demandante; sin embargo, la jurisprudencia en relación con la crisis argentina no es constante sobre

32 Thunderbird c México, supra nota 27, párr. 147.

33 Ibidem, parr. 164.

34 Ibidem, parr. 150.

35 Ibidem, parr. 166. Véase también: Glamis Gold Ltd v Estados Unidos, Ad hoc-UNCITRAL Arbitration Rules, laudo, 14 de mayo de 2009.

${ }^{36}$ LG\&E v Argentina, Decisión sobre responsabilidad, 3 October 2006, párr. 133: "Argentina, conjuntamente con la banca de inversión, diseñó atractivos paquetes jurídicos que garantizaban protección a cada una de las preocupaciones de los inversionistas extranjeros con relación al riesgo país argentino. En vista de tales riesgos, las Demandantes confiaron en garantías claves que ofrecían la Ley del Gas y su Reglamento... Al crear expectativas específicas entre los inversionistas, Argentina estaba vinculada por sus obligaciones relativas a las garantías ofrecidas a las inversiones, en particular para con las licenciatarias de distribución del gas. La derogatoria de estas garantías específicas viola la estabilidad y previsibilidad que yace en el estándar de trato justo y equitativo”. 
este punto. En Continental c. Argentina el tribunal parece haber tenido una visión más restrictiva al momento de analizar los compromisos específicos en el marco del trato justo y equitativo, si bien diferenció su análisis de aquél efectuado en otros litigios contra Argentina. En efecto, el tribunal consideró que:

Para evaluar la pertinencia de ese concepto aplicado dentro del estándar de trato justo y equitativo y establecer si se ha producido un incumplimiento, son factores pertinentes:

i) la especificidad del compromiso que se alega, factor mayormente ausente aquí, considerando, además, que las declaraciones políticas son, lamentable pero notoriamente, las que menos valor jurídico poseen;

ii) el hecho de que los enunciados legislativos generales generan escasas expectativas, especialmente cuando se trata de grandes inversionistas internacionales competentes en un contexto de alto riesgo político. Esas normas están, por naturaleza, sujetas a ulteriores modificaciones, y quizás a revocación y cancelación, dentro de los límites del respeto de los derechos humanos fundamentales y del ius cogens;

iii) la modificación unilateral de compromisos contractuales asumidos por Gobiernos, en especial cuando se realizan conforme a un marco legislativo y están destinados a obtener recursos financieros de inversionistas, evidentemente merece un examen más detenido a la luz del contexto, las razones y los efectos de esos compromisos, que habitualmente generan derechos y, por lo tanto, expectativas de cumplimiento;

iv) el carácter central para la inversión protegida y el impacto de las modificaciones sobre el funcionamiento de las empresas de propiedad extranjera en general, incluida su rentabilidad; la buena fe, la ausencia de discriminación (el alcance general de las Medidas impugnadas conforme al estándar), la importancia del interés público que persigue el Estado, las medidas paralelas encaminadas a reducir el impacto negativo son también factores que deben tenerse en cuenta para determinar si el trato ha sido justo. ${ }^{37}$

En la práctica, el empleo de uno u otro concepto así como el test aplicable para determinar el impacto de los compromisos específicos puede

37 Continental Casualty c. Argentina, supra nota 12, párr. 261. 
variar según se trate de una hipótesis de expropiación, de trato justo y equitativo o de las denominadas "cláusulas paraguas" (umbrella clauses).

\section{Variaciones según el estándar de protección en juego}

En el marco de la expropiación el concepto de compromiso específico suele ser relevante a los fines de determinar si el Estado renunció a su potestad de adoptar medidas regulatorias. En efecto, ciertos tribunales han considerado que no cumplir con compromisos específicos asumidos por el Estado receptor puede jugar un rol decisivo en la determinación de si una expropiación indirecta ha tenido lugar. En el caso Methanex c. Estados Unidos, el tribunal sostuvo lo siguiente:

En opinión del Tribunal, Methanex está en lo cierto respecto de que un reglamento intencionalmente discriminatorio en contra de un inversionista extranjero cumple con una condición clave para el establecimiento de la expropiación. ${ }^{38}$

Sin embargo, dado que la renuncia del Estado a ejercer sus poderes regulatorios no puede ser presumida, ${ }^{39}$ sólo ciertos compromisos claros y específicos serían susceptibles de obligar al Estado. Es lo que sugiere el tribunal en Methanex c. Estados Unidos ${ }^{40}$ cuando se refiere a los compromisos susceptibles de operar como excepción a la doctrina de los poderes de policía:

[C]omo cuestión de derecho internacional general, una reglamentación no discriminatoria con un fin público, que se dicta de conformidad con el debido proceso y que afecta, inter alios, a un inversionista extranjero o a una inversión no se con-

38 Methanex c. Estados Unidos, supra nota 4, parte IV capítulo D (3), párrafo 7 (nuestra traducción del original en inglés).

39 De acuerdo con el principio de que las restricciones a la soberanía de los estados no pueden presumerise. Véase Caso del S.S. “Lotus”, 1927 P.C.I.J. (ser. A), núm. 10 (Sept. 7) en 18; Caso de las Zonas Francas de Alta Savoya y del distrito de Gex (segunda fase), 1930 P.C.I.J. (ser. A) núm. 24, en 12 (Dec. 6); Caso de las Zonas Francas de Alta Savoya y del distrito de Gex, 1932 P.C.I.J. (ser. A./B.) núm. 46, en 167.

40 Methanex c. Estados Unidos, supra nota 4 
sidera expropiatoria e indemnizable a menos que se hayan asumido compromisos específicos por el gobierno regulador en relación con el inversionista extranjero, que en aquel entonces contemplaba una inversión, que el gobierno se abstendría de dicha regulación. ${ }^{41}$

Según esta posición los requisitos para que un acto califique en tanto compromiso específico (en el marco de una reclamación sobre expropiación) son los siguientes: (1) el compromiso debe haber sido emitido por el gobierno regulador, (2) el compromiso debe estar dirigido al inversionista en particular (3) el compromiso debe contener una obligación en virtud de la cual el gobierno se abstendrá de adoptar medidas regulatorias respecto de la inversión en particular. A esto debe agregarse la exigencia de que el inversionista se haya basado efectivamente en el compromiso cuando hizo su inversión (4). En efecto, el tribunal en Methanex destacó, a este respecto, que el inversionista era plenamente consciente del cambio constante de las medidas de protección del medio ambiente y la salud a nivel federal y estatal. Según el tribunal, el inversionista:

no entró en el mercado de Estados Unidos a causa de las representaciones especiales hechas a la misma. Por lo tanto este caso no es como Revere, donde se hicieron compromisos específicos de que se respetarían determinadas restricciones respecto de futuras medidas reglamentarias para inducir a los inversores a entrar en un mercado y luego los compromisos no se cumplieron. ${ }^{42}$

En resumen, el laudo Methanex c. Estados Unidos sugiere que sólo aquellos compromisos que cumplan con ciertos requisitos de especificidad (compromiso asumido por el gobierno regulador; dirigido al inversionista; tendiente a no adoptar ciertas medidas en relación con la inversión en particular; inversión efectuada con base en dicho compromiso). Sólo en dicha hipótesis podría protegerse una expectativa del inversionista con respecto a un compromiso.

Una concepción similarmente restrictiva de los eventuales compromisos asumidos por el Estado receptor ha sido desarrollada en relación

41 Ibidem, parte IV capítulo D (3), párrafo 7 (nuestra traducción del original en inglés) (énfasis agregado).

42 Ibidem, párrafo 10 (nuestra traducción del original en inglés). 
con las cláusulas paraguas, que a menudo se refieren a las garantías o compromisos específicos. Las observaciones del comité de anulación en el caso CMS c. Argentina ${ }^{43}$ con respecto a la cláusula paraguas del TBI Argentina-Estados $\operatorname{Unidos}^{44}$ permiten ilustrar este punto:

(a) En cuanto señala "los compromisos que hubiera contraído con respecto a las inversiones", parece claro que el Artículo II(2)(c) se refiere a obligaciones consensuales que derivan independientemente del propio TBI (i.e. conforme al derecho del Estado receptor o posiblemente al derecho internacional). Más aún, debe tratarse de obligaciones específicas relativas a la inversión. Estas no comprenden requisitos generales impuestos por el derecho del Estado receptor.

(b) Las obligaciones consensuales no se contraen erga omnes sino con respecto a personas determinadas. Similarmente, el cumplimiento de dichas obligaciones o requisitos se produce entre deudor y acreedor.

(d) La obligación del Estado comprendida en el Artículo II(2)(c) a menudo es una obligación bilateral o una obligación intrínsecamente asociada a las obligaciones de la sociedad de inversión... ${ }^{45}$

El ejemplo básico que se tiene en mente es, naturalmente, el compromiso asumido en virtud de un contrato entre el Estado receptor y el inversionista, aunque otras hipótesis puedan ser contempladas. ${ }^{46}$ Tanto en materia de expropiación como en materia de cláusulas paraguas, el énfasis se sitúa en la especificidad del compromiso, la cual explica que se protejan las expectativas del inversionista.

La situación precedente puede ser contrastada con el modo en que los conceptos de expectativa legítima y compromiso específico operan en relación con la aplicación del estándar de trato justo y equitativo. En este contexto, las exigencias de especificidad no parecen aplicarse del mismo modo. Por ejemplo, en el caso Metalclad c. Mexico, que fue uno

43 CMS c. Argentina, Anulación, supra nota 12.

44 ElTBI Argentina-Estados Unidos establece, en su artículo II.2.c), que: "Cada Parte cumplirá los compromisos que hubiera contraído con respecto a las inversiones”.

45 CMS c. Argentina, Anulación, supra nota 12, párrafo 95.

46 Sinclair, A. C., "The Origins of the Umbrella Clause in the International Law of Investment Protection”, 20 Arbitration International 411, 2004 en 422. 
de los primeros que se refirió a las "expectativas" de los inversionistas al analizar el trato justo y equitativo, ${ }^{47}$ el tribunal consideró que la negativa de las autoridades locales mexicanas de emitir un permiso de construcción por motivos ambientales había sido contraria a las garantías anteriores recibidas por el inversionista de las autoridades federales mexicanas; ${ }^{48} \sin$ embargo, a requerimiento de México, el laudo fue parcialmente anulado por la Corte Suprema de Columbia Británica sobre la base de que el tribunal había excedido sus poderes al introducir una obligación de transparencia en el artículo 1105 del TLCAN y decidir la controversia sobre esa base. ${ }^{49}$ De modo similar, el tribunal en el caso Waste Management c. México consideró que: "Al aplicar [el trato mínimo internacional] es pertinente que el trato sea contrario y violatorio de las declaraciones hechas por el Estado receptor sobre las que el demandante se basó en forma razonable”. ${ }^{50}$ Otro tribunal que se refirió al concepto de expectativas legítimas del inversionista es el del caso Tecmed c. México:

El Tribunal Arbitral considera que [el trato justo y equitativo], a la luz de los imperativos de buena fe requeridos por el derecho internacional, exige de las Partes Contratantes del Acuerdo brindar un tratamiento a la inversión extranjera que no desvirtúe las expectativas básicas en razón de las cuales el inversor extranjero decidió realizar su inversión. Como parte de tales expectativas, aquél cuenta con que el Estado receptor de la inversión se conducirá de manera coherente, desprovista de ambigüedades y transparente en sus relaciones con el inversor extranjero, de manera que éste pueda conocer de manera anticipada, para planificar sus actividades y ajustar su conducta, no sólo las normas o reglamentaciones que regirán

47 Metalclad Corp v México, Caso CIADI núm. ARB(AF)/97/1, Laudo, 25 de agosto de 2000 ("Metalclad Corp v México").

48 El tribunal sotuvo: "Metalclad podía permitirse confiar en las afirmaciones de los funcionarios federales y creer que estaba autorizada a continuar con la construcción del confinamiento. Siguiendo el consejo de estos funcionarios, y presentando el 15 de noviembre de 1994 una solicitud para un permiso municipal, Metalclad sólo actuaba de manera prudente y con la total expectativa de que el permiso se otorgaría.”, ibidem, párr. 89.

49 Véase Estados Unidos Mexicanos c. Metalclad, 2001 BCSC 664, Supreme Court of British Columbia, Reasons for the Judgment (2 May 2001), párr. 67-77.

50 Waste Management Inc c. México, Laudo, Caso CIADI No. ARB(AF)/00/3, 30 de abril de 2004, párr. 98. 
tales actividades, sino también las políticas perseguidas por tal normativa y las prácticas o directivas administrativas que les son relevantes... ${ }^{51}$

Es importante subrayar que la base de las expectativas legítimas en este caso no son los compromisos específicos, sino las expectativas de coherencia, claridad y transparencia. Este caso ha sido objeto de críticas, inclusive por parte de la jurisprudencia posterior; ${ }^{52}$ sin embargo, la línea de razonamiento del tribunal en Tecmed fue retomada posteriormente por ciertos tribunales en el contexto de litigios contra la Argentina $^{53}$ así como en otros contextos. ${ }^{54}$

Este breve análisis sugiere que el empleo de los conceptos de "expectativas legítimas” y de “compromisos específicos” varía según el estándar de protección de las inversiones involucrado. La variación afecta no sólo la selección de uno u otro concepto (compromiso específico en el ámbito de las cláusulas de expropiación y de las cláusulas paraguas, y expectativas legítimas en el ámbito del estándar de trato justo y equitativo) sino también, como resultado de dicha selección, el nivel de exigencia

51 Técnicas Medioambientales Tecmed SA c. México, Laudo, ARB(AF)/00/2, 29 de mayo de 2003, párr. 154.

52 Por ejemplo, el comité de anulación en el caso MTD c. Chile observó lo siguiente: "La confianza aparente del Tribunal TECMED en las expectativas de los inversores extranjeros como fuente de las obligaciones del Estado receptor (como la obligación de indemnizar por la expropiación) es cuestionable. Las obligaciones del Estado receptor hacia los inversores extranjeros se derivan de los términos del tratado de inversión aplicables y no de un conjunto de expectativas de los inversores pueden tener o dicen tener. Un tribunal que trata de generar expectativas de un conjunto de derechos diferentes de los contenidos o exigibles en virtud del TBI podría exceder sus poderes, y si la diferencia fuese material podría hacerlo de forma manifiesta”, MTD Equity Sdn Bhd and MTD Chile SA c. Chile, Decisión sobre anulación, Caso CIADI No. ARB/01/7, 16 de febrero de 2007, párr. 67.

53 Véase CMS c. Argentina CMS c.Argentina, Anulación, supra nota 12, párrafo 89: "Aunque de una negociación entre el inversionista y el Estado receptor de la inversión pudieren emanar legítimas expectativas, estas, como tales, no constituyen obligaciones legales, a pesar de que puedan ser de importancia para la aplicación de la cláusula de trato justo y equitativo contenida en el TBI”. parr. 89. Ver también: CMS c. Argentina, Laudo, supra nota 12, párrafo 279 Azurix Corp c Argentina, Laudo, Caso CIADI n ARB/01/12, 23 de junio 2006 (“Azuri c Argentina”), párrafo 316; LG\&E-Responsabilidad, párrafo 127; Suez c. Argentina-03/17, Decisión sobre responsabilidad, párrafo 205; pero ver la opinión dicidente del árbitro Nikken, párrafos 22-26.

54 El tribunal en Saluka c. República Checa afirmó lo siguiente: "[e]l estándar de "trato justo y equitativo" está estrechamente ligado a la noción de expectativa legítima que es el elemento dominante de dicho estándar”. Saluka c. República Checa, supra nota 24, párrafo 302. 
con que se juzgará la situación de hecho. Dicho nivel será, en principio, más alto cuando se plantee la cuestión de la existencia de "compromisos específicos” en sentido estricto. Esta cuestión es de particular importancia para nuestro análisis, dado que la existencia de compromisos específicos ha sido afirmada en tanto excepción a la aplicación de la doctrina de los poderes de policía del Estado. ${ }^{55}$

\section{Fundamento y efecto de los compromisos específicos}

Los casos mencionados en los puntos precedentes ponen de manifiesto la importancia que tienen para algunos tribunales los compromisos específicos acordados a un inversionista extranjero; sin embargo, el fundamento y el efecto de dichos compromisos específicos requieren ciertas precisiones suplementarias.

La cuestión del fundamento del carácter vinculante de los compromisos específicos ha sido debatida por la doctrina. Se suele indicar, como fundamentos posibles, la buena fe, la doctrina del estoppel, o la teoría de los actos unilaterales de los Estados en derecho internacional; ${ }^{56}$ sin embargo, a pesar de que existen similitudes con estos conceptos, resulta difícil realizar una asimilación completa. En particular, los efectos de los actos unilaterales están sujetos a ciertas condiciones, entre las cuales cabe mencionar la intención del Estado que realiza la declaración de que la misma lo obligue de acuerdo con sus términos y una publicidad suficiente, ${ }^{57}$ la capacidad del individuo que la emite de obligar al Estado, ${ }^{58}$ y la situación del destinatario, el cual suele ser un sujeto de derecho internacional. ${ }^{59}$ Los tribunales que se han pronunciado sobre el efecto (potencial) de los compromisos específicos asumidos por el Estado receptor adoptan una posición más flexible en relación con las condiciones que dichos compromisos deben respetar. El emisor de las garantías

55 Véase supra sección I(B).

56 Véase R. Dolzer y C. Schreuer, Principles of International Investment Law, Oxford University Press, 2008, p. 6.

57 Caso de los ensayos nucleares (Australia v. Francia), 1974 I.C.J. 253, en 267, párrafo 43.

58 Ibidem 269, párrafo 49.

59 Ibidem, párrafo 51. 
no es necesariamente un individuo capaz de obligar internacionalmente al Estado, la condición de publicidad no siempre se cumple y, en todo caso, el acto se dirige a un inversionista, cuya subjetividad internacional es muy controvertida. Por otra parte, los tribunales internacionales han considerado como fuente de garantías, o compromisos específicos, entre otras, a la legislación de un gobierno (nacional, provincial o municipal), la reglamentación, los contratos administrativos, e inclusive las declaraciones de funcionarios.

A la ambigüedad relativa al fundamento de los compromisos específicos debe agregarse aquélla relativa al efecto de un compromiso específico. Como lo mencionamos en la sección precedente, según el estándar en el ámbito del cual se analiza esta cuestión, (1) un compromiso específico podrá ser considerado como una renuncia, por parte del Estado, a su potestad de adoptar medidas regulatorias, (2) como una obligación protegida en virtud de una cláusula paraguas o (3) como prueba de la legitimidad de las expectativas de un inversionista.

En el marco de reclamos por medidas ambientales, la cuestión que se plantea es en qué medida los efectos mencionados se verían afectados por las particularidades de la protección ambiental. Por ejemplo, podríamos preguntarnos hasta qué punto las garantías o compromisos específicos serían suficientes para dar prioridad a las cláusulas de protección de la inversión frente a medidas ambientales en aquellos casos en los que un gobierno anterior del Estado receptor ha asumido compromisos específicos omitiendo conscientemente la posibilidad de un impacto ambiental negativo. En tal situación, dos valores entrarían en competencia, a saber, la necesidad legítima de proteger el medio ambiente y las expectativas razonables de los inversionistas al realizar la inversión. Aunque los tribunales en el caso Metalclad c. México, MTD c. Chile y Methanex c. Estados Unidos le hayan dado prioridad al segundo término del dilema, ciertos pasajes de dichos laudos matizan esta conclusión, al subrayar el carácter legítimo de las preocupaciones ambientales del Estado receptor, ${ }^{60}$ así como la necesidad, para el inversionista, de prever

60 Véase Metalclad v. Mexico, en el que el tribunal observó que su conclusión no se veía afectada por el artículo 1114 del TLCAN, el cual: "Permite que una Parte se asegure que las inversiones se efectúen tomando en cuenta inquietudes en materia ambiental no afecta esta conclusión. La celebración del Convenio y el otorgamiento de los permisos federales mues- 
razonablemente la evolución de la reglamentación ambiental. ${ }^{61}$ Ello sugiere que no cualquier compromiso específico podría ser razonablemente invocado por un inversionista cuyo nivel de diligencia razonable incluye el de ser consciente de la creciente demanda de protección del medio ambiente. ${ }^{62}$ Es así, por ejemplo, que en Chemtura c. Canadá el tribunal consideró que la parte demandante, como experimentado actor en una industria altamente regulada, no podía razonablemente ignorar las prácticas de la agencia regulatoria de control de pestes y la importancia de la evaluación de los riesgos de exposición dentro de esas prácticas. ${ }^{63}$ Esto sugeriría que las reales amenazas ambientales a veces pueden prevalecer sobre ciertas garantías específicas.

Desde un punto de vista conceptual, la relación entre los efectos de los compromisos específicos y la protección ambiental plantea tres cuestiones distintas. En primer lugar, debe determinarse en qué medida las particularidades de la protección ambiental deben ser tomadas en cuenta en la caracterización de ciertas garantías como compromisos específicos susceptibles de desencadenar los efectos usuales. En particular, se trata de determinar el carácter legítimo o razonable de las expectativas del inversionista en el marco del análisis de una violación

tran claramente que México estaba satisfecho con el hecho de que el proyecto era acorde con y tomaba en cuenta inquietudes en materia ambiental", Metalclad v. Mexico, supra nota 47, párr. 98.

${ }^{61}$ Véase Methanex v. Estados Unidos, en el que el tribunal observó lo siguiente, en relación con la cuestión de los compromisos específicos: "[n]o such commitments were given to Methanex. Methanex entered a political economy in which it was widely known, if not notorious, that governmental environmental and health protection institutions at the federal and state level, operating under the vigilant eyes of the media, interested corporations, nongovernmental organizations and a politically active electorate, continuously monitored the use and impact of chemical compounds and commonly prohibited or restricted the use of some of those compounds for environmental and/or health reasons... Methanex entered the Estados Unidos market aware of and actively participating in the process. It did not enter the Estados Unidos market because of special representations made to it", Methanex v. Estados Unidos, supra nota 4 parte IV, capítulo. D, párr. 9-10.

62 En Bayindir c. Pakistan, el tribunal consideró que el inversionista no podía invocar, razonamblemente, ciertos compromisos específicos cuyo tenor dependía totalmente de la evolución política del país, el cual se encontraba en una fase particularmente inestable, Bayindir Insaat Turizm Ticaret ve Sanayi A Ş c. Pakistán, Laudo, Caso CIADI núm. ARB/03/29, 24 de agosto de 2009 (“Bayindir c. Pakistán”), párr. 193-194.

63 Chemtura c. Canadá, supra nota 4, párr. 149. 
eventual de una cláusula de protección de inversiones. En segundo lugar, aun si se concluye que el comportamiento del Estado receptor se encuentra en violación de una cláusula de protección de inversiones, también debe determinarse el nivel de diligencia desplegada por el inversionista, ya que ello constituye un paso necesario para saber qué parte del daño debe ser asumida por el inversionista a título de riesgo empresarial. En tercer lugar, aun si el comportamiento del inversionista fuese irreprochable, la protección de ciertos intereses ambientales puede prevalecer sobre la protección de los intereses de los inversionistas. Según el interés en cuestión, las consecuencias se manifestarán sobre el plano de la responsabilidad o sobre el plano de la indemnización. Las respuestas a cada una de estas tres cuestiones representan diversos modos de distribuir el riesgo regulatorio en materia ambiental.

\section{LA DISTRIBUCIÓN DEL RIESGO REGULATORIO}

EN MATERIA AMBIENTAL

\section{Carácter razonable /legítimo de las expectativas}

El primer modo de distribuir el riesgo regulatorio en materia ambiental aun en presencia de garantías específicas es a través del análisis del carácter razonable y/o legítimo de las expectativas del inversionista. Conceptualmente, se trata de determinar si las circunstancias en que las garantías o compromisos fueron comunicados al inversionista impiden que éste los invoque en el marco de una reclamación por violación de un TBI. Según el estándar de protección de inversiones en cuestión, el análisis se concentrará en diversos elementos, como la buena fe del inversionista o la razonabilidad de la expectativa invocada, la cual a su vez dependerá de la especificidad de los actos que se invocan como base de la expectativa. Independientemente de estos elementos, el objeto del análisis será determinar si el Estado responsable infringió o no una cláusula de protección de inversiones.

Para ilustrar el funcionamiento de este mecanismo de distribución podemos referirnos a ciertos casos en que la cuestión se planteó de 
modo relativamente claro, aun si in casu no se trataba de medidas ambientales. Por ejemplo, en el caso Generation c. Ucrania el tribunal analizó la razonabilidad de las expectativas invocadas por el inversionista a la luz de las circunstancias en que dichas expectativas se formaron. ${ }^{64}$ Una compañía de la parte demandante había celebrado un contrato con el municipio de Kiev para la construcción de un edificio de oficinas. El inversionista alegó que las autoridades locales habían obstruido la realización del proyecto y que su conducta era equivalente a una expropiación. El tribunal consideró, sin embargo, que las expectativas invocadas por el inversionista no eran razonables:

[E]s importante tener en cuenta las vicisitudes de la economía del estado que alberga a la inversión en la determinación de las expectativas legítimas de los inversores, cuya protección es una de las principales preocupaciones de las normas mínimas de trato que contienen los tratados bilaterales de inversión. El demandante fue atraído a Ucrania debido a la posibilidad de obtener una tasa de retorno sobre el capital ampliamente superior a las oportunidades de inversión en otras economías más desarrolladas. El demandante en consecuencia invirtió en Ucrania conociendo perspectivas y los riesgos potenciales. Su inversión fue especulativa. ${ }^{65}$

Por estos motivos el tribunal de Generation rechazó la reclamación del inversionista por violación de la cláusula de expropiación. Siguiendo un razonamiento similar, el tribunal en Bayindir c. Pakistan brinda otro ejemplo del mismo mecanismo. En este caso, el inversionista había solicitado una indemnización a raíz de una disputa sobre la construcción de una carretera alegando que Pakistán había rescindido el contrato por motivos políticos. El tribunal consideró las circunstancias que deben tenerse en cuenta al analizar la razonabilidad y/o legitimidad de las expectativas de la parte demandante ${ }^{66}$ concluyendo que ésta no podía "razonablemente haber ignorado la volatilidad y las condiciones políticas que prevalecían

64 Generation Ukraine, Inc c. Ucrania, Laudo, Caso CIADI núm. ARB/00/9, 15 de septiembre 2003.

65 Ibidem, párr. 20.37 (nuestra traducción del original en inglés).

66 Bayindir c. Pakistán, supra nota 62, párr. 192 (nuestra traducción del original en inglés). 
en Pakistán al momento en que acordó revivir el contrato" ${ }^{67}$ El tribunal agregó a este respecto que:

Bayindir entró en el Contrato con pleno conocimiento de estas circunstancias. Resulta difícil aceptar ahora que Bayindir tenía expectativas de mayor estabilidad y previsibilidad para justificar la protección con arreglo a la norma de [trato justo y equitativo]. ${ }^{68}$

En consecuencia, la reclamación de Bayindir relativa a la frustración de sus expectativas legítimas fue rechazada.

El mismo tipo de razonamiento puede aplicarse en el ámbito de la reglamentación ambiental. Dos hipótesis principales pueden ser identificadas. En primer lugar, podría pensarse en un caso en que el inversionista ha invertido en una actividad potencialmente riesgosa para el medio ambiente (por ejemplo, el tratamiento de desechos peligrosos con tecnologías inferiores a las empleadas en otros países) por haber recibido ciertas garantías por parte de un gobierno inescrupuloso, poco diligente o incompetente. Si posteriormente, el gobierno del Estado receptor cambiara y adoptara una medida ambiental razonable cuyo efecto fuera perjudicial para el inversionista, éste no debería poder invocar las garantías que le fueron dadas inicialmente. En efecto, en dicho caso el inversionista habría invertido conociendo los riesgos potenciales de la inversión — con el fin de obtener una tasa de rentabilidad superior a la normal - y sus expectativas de que el gobierno no se comportará de modo diligente no deberían ser protegidas. Esta primera hipótesis admite matices, según que el inversionista haya actuado de mala fe o simplemente haya aceptado un riesgo regulatorio superior al normal. En segundo lugar podría pensarse en una situación en que el mercado en que opera el inversionista se encuentra sujeto, por su naturaleza misma, a ciertos riesgos regulatorios. Por ejemplo, un productor de medicamentos o de pesticidas a base de ingredientes cuyo riesgo es puesto de manifiesto por el avance del conocimiento científico. Esta situación también admite varios matices, ya que en ciertos casos (por ejemplo la producción de DDT como pesticida en los países en vías de desarro-

67 Ibidem, 193.

68 Ibidem, 194. 
llo afectados por el paludismo), la aceptación de un riesgo regulatorio anormal podría ser inducida directamente por las necesidades del Estado receptor, volviendo así los compromisos específicos asumidos por éste razonables desde el punto de vista de un inversionista; sin embargo, el test aplicable a los compromisos específicos sería más exigente en dicho caso que uno normal, en el cual el inversionista ha decidido operar en un sector riesgoso y debe, por ende, asumir el riesgo que ello acarrea.

En ambas hipótesis, y sobre todo en la segunda, se plantea una cuestión difícil de política judicial o arbitral, a saber, en qué medida la solución sugerida equivaldría a favorecer la posición de Estados políticamente inestables, los cuáles podrían invocar su propia inestabilidad para deshacerse de sus obligaciones internacionales en materia de protección de inversiones. La cuestión es delicada y, naturalmente, debería ser resuelta a la luz de las circunstancias particulares de cada caso. $\mathrm{Si}$ el tribunal llegara a la conclusión que tanto el inversionista como el Estado receptor deben soportar parte de la responsabilidad, la solución consistiría, como se verá a continuación, en distribuir el riesgo regulatorio a nivel de la indemnización y no de la responsabilidad, la cual sería admitida.

\section{Contribución al daño}

El nivel de diligencia del inversionista puede ser un factor importante no sólo para juzgar la razonabilidad de sus expectativas o de su reacción en relación con un supuesto compromiso específico sino también para distribuir el riesgo regulatorio sobre el plano de las consecuencias pecuniarias de la medida ambiental.

De modo general existen dos enfoques opuestos en lo que respecta a la indemnización por expropiación regulatoria ambiental. ${ }^{69}$

El primero presta a las justificaciones medioambientales una importancia limitada (tesis de la irrelevancia). Esta tesis se centra sólo en los efectos de la privación de la propiedad y sostiene que una expropiación debe ser compensada independientemente de sus motivos. Los laudos

69 V'éase Viñuales, suptra nota 2 , pp. 324 y ss. 
en CDSE c. Costa Rica ${ }^{70}$ y Metalclad c. México ilustran esta primer postura. La disputa en CDSE c. Costa Rica se refería al importe adeudado por la expropiación directa de un lote de tierra que la parte demandante había adquirido con el fin de construir un centro turístico. El demandado invocó una serie de instrumentos ambientales nacionales e internacionales para impugnar el cálculo de la cuantía de la indemnización. ${ }^{71}$ El tribunal sólo tuvo en cuenta dichos instrumentos en relación con el objetivo público de la expropiación sin que ello tuviera repercusiones sobre la determinación de la indemnización. ${ }^{72}$ Esta postura fue confirmada en el caso Metalclad c. México en relación con una expropiación regulatoria. En este caso, el tribunal sostuvo que independientemente de los motivos ambientales invocados por el Estado receptor, las medidas constituían una infracción a los artículos 1105 (estándar mínimo de trato) y 1110 (expropiación) del TLCAN. ${ }^{73}$

70 CDSE v. Costa Rica, supra nota 8.

71 Aunque dichos instrumentos no figuren en el laudo, nos consta que tal fue el caso, como lo demuestra un artículo escrito por el abogado de Costa Rica en este caso. Véase Brower, C. N. y Wong, J., "General Valuation Principles: The Case of Santa Elena”, in International Investment Law and Arbitration: Leading Cases from the ICSID, NAFTA, Bilateral Treaties and Customary International Law 764, Weiler T. ed., London, Cameron May, 2005.

72 El tribunal sostuvo lo siguiente: "Mientras que una expropiación o una toma por razones ambientales se pueden clasificar como realizadas a causa de una utilidad pública, y por lo tanto pueden ser legítimas, el hecho de que los bienes fueron confiscados por este motivo no afecta a la naturaleza o la medida de la indemnización a pagar por la toma. Es decir, el fin de proteger el medio ambiente para la toma de la propiedad no altera la naturaleza jurídica de la adopción por quién debe pagar una indemnización adecuada. La fuente internacional de la obligación de proteger el medio ambiente no hace ninguna diferencia”, CDSE c. Costa Rica, suptra nota 8 , párr. 71 .

73 En particular, el tribunal sostuvo lo siguiente: "[a]unque no es estrictamente necesario para su conclusión, el Tribunal considera el Decreto Ecológico dictado por el Gobernador de SLP el 20 de septiembre de 1997 como un fundamento más para su decisión respecto a la expropiación. El Decreto cubre un área de 188,758 hectáreas dentro de "Real de Guadalcázar" lo que incluye el lugar del confinamiento, y crea ahí una reserva ecológica. Este Decreto tuvo como efecto el impedir para siempre la operación del confinamiento... El Tribunal no está convencido con la alegación contraria de México. El artículo noveno, por ejemplo, prohíbe cualquier trabajo incompatible con el programa de manejo del Decreto Ecológico. El programa de manejo se define en el artículo quinto como un diagnóstico de los problemas ecológicos del cactus de la reserva y como la preservación ecológica de éste. Además, el artículo catorce del Decreto prohíbe toda conducta que pueda implicar la descarga de contaminantes en el suelo, subsuelo y en toda clase de corrientes o depósitos de agua, así como el desarro- 
El segundo enfoque adoptado por ciertos tribunales sostiene que las expropiaciones por motivos ambientales no son indemnizables ya que no violan las cláusulas de protección de los inversionistas. Esta postura está basada principalmente en una aplicación de la doctrina de los poderes de policía, la cual ha sido expuesta en la primera sección del presente estudio (sección I.B supra); sin embargo, cabe destacar que, como lo vimos en relación con el carácter razonable-legítimo de las expectativas del inversionista (sección III.A supra), dicha postura podría extenderse a casos en que, a pesar de ciertas declaraciones o garantías dadas al inversionista, las circunstancias del caso le impiden a éste buscar refugio en dichas declaraciones o garantías. Queda abierta la cuestión, planteada anteriormente, de la falta de diligencia del Estado receptor.

A este respecto, podemos referirnos a un tercer enfoque en materia de indemnización, que ha sido utilizado por ciertos tribunales de inversión. Según esta postura el riesgo regulatorio debe ser distribuido al determinarse la indemnización, determinación que tomará en cuenta el nivel de diligencia del inversionista y del Estado receptor para distribuir los daños de modo proporcional. Los siguientes tres ejemplos permiten ilustrar este enfoque. En MTD c. Chile, el tribunal determinó que el demandado había violado el estándar de trato justo y equitativo, ya que diferentes entes regulatorios habían asumido compromisos contradictorios en relación con el inversionista; sin embargo, tomando en cuenta la negligencia del inversionista en la evaluación del riesgo regulatorio al que se exponía, el tribunal consideró que éste debía soportar una parte de los daños que había sufrido como resultado de su propio riesgo empresarial, ya que "[l]os tratados bilaterales de inversión no son un seguro

llo de actividades contaminantes. El artículo quince del Decreto Ecológico también prohíbe toda actividad que requiera permisos o licencias excepto aquella actividad relacionada con la exploración, extracción y utilización de los recursos naturales... El Tribunal no necesita considerar los motivos o intención para la adopción del Decreto Ecológico. De hecho, el determinar una expropiación basándose en el Decreto Ecológico, no es esencial para que el Tribunal considere que se ha violado el artículo 1110 del TLCAN. Sin embargo, el Tribunal considera que la implementación del Decreto Ecológico podría, por sí y en sí mismo, constituir un acto equivalente a una expropiación”, Metalclad c. México, supra nota 47, párrs. 109111. Como ya ha sido mencionado, el laudo fue parcialmente anulado por la Corte Suprema de Columbia Británica. 
contra los riesgos de negocios". ${ }^{74}$ El tribunal consideró, en efecto, que el inversionista podría haber mitigado tal daño si hubiese desplegado un mejor análisis del negocio:

El Tribunal decidió antes que los Demandantes incurrieron en gastos que están relacionados con su juicio de los negocios, independientemente de la violación del trato justo y equitativo bajo elTBI. Como ya se señaló, los Demandantes, en el momento de su contrato..., habían tomado decisiones que el aumento de los riesgos en la operación y para los que tienen la responsabilidad, independientemente del tratamiento dado por Chile a los demandantes. Se aceptó pagar un precio por la tierra con el proyecto sin la debida protección legal. Un inversor prudente no habría pagado el precio completo por adelantado de terrenos valuados en el supuesto de la realización del proyecto, por lo menos habría establecido pagos futuros de acuerdo con la marcha del proyecto, incluida la emisión de los permisos de desarrollo requeridos... El Tribunal considera, pues, que los demandantes deben soportar una parte de los daños sufridos y el Tribunal estima que la cuota será del $50 \%$ una vez deducido el valor residual de su inversión. ${ }^{75}$

La segunda ilustración a la que podemos referirnos es el caso Bogdanov c. Moldavia ${ }^{76}$ en el que el tribunal también redujo la indemnización debida por el Estado receptor como resultado de la conducta del inversionista. Una compañía propiedad del inversionista, había celebrado un contrato de privatización con Moldavia para la compra de una participación mayoritaria en una empresa estatal. El contrato establecía, que la compañía del demandante debía transferir determinados activos al Estado. El demandante alegó en el arbitraje que ciertas medidas adoptadas por Moldavia después de la celebración del contrato respecto al valor de los activos transferidos por la compañía eran contrarias al estándar de trato justo y equitativo contenido en el TBI Rusia-Moldavia. El tribunal determinó que Moldavia había violado dicho estándar; sin

74 MTD Equity Sdn Bhd and MTD Chile SA c. Chile, Laudo, Caso CIADI No. ARB/01/7, 25 de mayo 2004, párr. 178,

75 Ibidem, párr. 242-243. La evaluación de los daños del tribunal resistió un pedido de anulación, véase el MTD c. Chile Decisión sobre Anulación, supra nota 52, párr. 101.

76 Bogdanov y otros c. Moldavia, Laudo, Reglamento de Arbitraje de la SCC, 22 de septiembre de 2005. 
embargo, al determinar los daños tuvo en cuenta los riesgos asumidos por el inversionista:

El Tribunal Arbitral no considera que el Demandado sea la persona responsable del pago de la indemnización correspondiente a la totalidad de las pérdidas, y que la empresa de inversión local debe considerarse en parte responsable de las pérdidas, ya que no se aseguró de que el contrato de privatización contuviera una regulación adecuada y precisa respecto de la indemnización. ${ }^{77}$

El tercer ejemplo nos lo brinda el caso Azurix c. Argentina.$^{78}$ En éste, el tribunal decidió que el demandante no había procedido de modo razonable al haber hecho un pago excesivamente alto por la concesión (asumiendo el riesgo de no recuperar el monto invertido), y en consecuencia atribuyó parte de la pérdida al análisis defectuoso del negocio efectuado por el inversionista y no a la conducta del Estado receptor. ${ }^{79}$ Este hecho tuvo un impacto importante en la determinación de los daños.

En resumen, aun en aquellos casos en que tanto el Estado receptor como el inversionista han faltado a su deber general de diligencia en relación con la adopción o la previsión, respectivamente, de una medida ambiental, existen modos de distribuir el riesgo regulatorio por medio de la determinación de la indemnización. Nótese a este respecto que dicho método puede operar tanto en el marco del estándar de trato justo y equitativo, en que los criterios de evaluación de daños son flexibles, como en el marco del estándar de expropiación, a pesar de la mayor rigidez de los criterios de evaluación de daños. Con relación a este último punto, podría procederse de diversos modos en la evaluación del valor presente (net present value) del activo expropiado (típicamente una empresa). Un modo sería introducir en dicha evaluación el daño ambiental que habría provocado una empresa en el futuro y sus consecuencias financieras para la empresa (riesgos de litigio, pérdida de clientes, etcétera); otro modo sería simplemente tomar en cuenta el marco regulatorio ambiental legítimo (independientemente de la conducta específica que

77 Ibidem, párr. 84 (nuestra traducción del original en inglés).

78 Azuri c Argentina, supra nota 52.

79 Ibidem, párr. 426-429. 
in casu constituye una violación de la cláusula de expropiación) en el que la empresa habría operado en el futuro así como las consecuencias de dicho marco para la rentabilidad de la empresa (hipotéticamente, si la empresa opera de modo nocivo para el medio ambiente, la proliferación de la reglamentación ambiental constituirá una desventaja y, por ende, disminuirá los ingresos futuros de la empresa que son tomados en cuenta al determinar su valor presente).

\section{La teoría de los intereses protegidos}

Incluso en aquellos casos en que las circunstancias en que el Estado receptor ha dado garantías específicas a un inversionista y, por consiguiente, ha renunciado a ejercer sus poderes regulatorios en relación con cierta cuestión ambiental, en algunas hipótesis el efecto de dicha renuncia debería verse limitado. La teoría de los intereses protegidos que expondremos a continuación vincula los dos métodos analizados anteriormente (determinación de la razonabilidad/legitimidad de las expectativas y contribución al daño en caso de omisión de diligencia) al tipo de interés ambiental que la medida adoptada por el Estado receptor en contravención de los compromisos específicos asumidos anteriormente intenta proteger. Según la importancia intrínseca del interés, el poder regulatorio del Estado debería poder desplegar todo su alcance o al menos introducir un elemento de proporcionalidad en la distribución de las consecuencias pecuniarias del riesgo regulatorio ambiental.

Nótese que las consideraciones que constituyen el substrato de esta postura pueden (y en algunos casos deberían) ser tomadas en cuenta conjuntamente con las consideraciones que fundan los dos métodos de distribución analizados anteriormente. Por ejemplo, la valoración de ciertos intereses, como la protección de la salud pública contra una sustancia cuyo efecto nocivo ha sido descubierto, con respecto al interés patrimonial de un inversionista podría al mismo tiempo ser conceptualizada como un riesgo intrínseco del mercado en que opera el inversionista y por ende afectar la razonabilidad de sus expectativas o la caracterización del nivel de diligencia debida; sin embargo, el argumento de base es distinto del que funda los métodos anteriores, ya que se trata 
en este caso de efectuar un juicio de valor sobre la importancia relativa de diversos valores. Dicha particularidad vuelve esta teoría de difícil aplicación práctica, al menos por el momento, ya que no sólo la jerarquía normativa de la protección del medio ambiente en derecho internacional sigue siendo controvertida ${ }^{80}$ sino que además los tribunales de inversión suelen ser reticentes ante la idea de pronunciarse claramente sobre la jerarquía normativa de las normas de protección del medio ambiente y de las inversiones, respectivamente $;^{81}$ sin embargo, nos parece útil mencionar cómo una teoría de los intereses protegidos podría ser desarrollada a la luz de la jurisprudencia internacional. Desde un punto de vista analítico, la valoración puede proceder de dos modos.

En primer lugar, la protección del medio ambiente puede fundarse en una obligación internacional. Es así por ejemplo que en el caso SPP c. Egipto, ${ }^{82}$ a pesar de haber llegado a la conclusión de que Egipto había expropiado al inversionista, el tribunal excluyó del cálculo de la indemnización los importes de los daños correspondientes al periodo posterior a la aparición (o exigibilidad) de las obligaciones de Egipto de conformidad con la Convención de la UNESCO sobre la Protección del Patrimonio Mundial, Cultural y Natural, de $1972 .{ }^{83}$ El tribunal razonó de la siguiente manera:

Incluso si el Tribunal estuviera dispuesto a aceptar la validez de los cálculos del Demandante de FCD [Flujo de Caja Descontado], sólo podría otorgar lucro cesante hasta 1979, cuando las obligaciones derivadas de la Convención de la

${ }^{80}$ Véase Viñuales, J. E., "La protección del medio ambiente y su jerarquía normativa en derecho internacional”, International Law. Revista Colombiana de Derecho Internacional, diciembre de 2008, pp. 11-44.

${ }^{81}$ Véase Viñuales, J. E., “Conflits de normes en droit international: normes environnementales vs. protection des investissements”, in Société française de droit international, Le droit international face aux enjeux environnementaux, colloque d'Aix-en-Provence (2009), París, Pedone, 2010, pp. 407-427. Una versión actualizada de este estudio en inglés será publicada como parte de un libro coordinado por Maljean-Dubois, S. et al., "Managing Conflicts between Environmental and Investment Norms”, en Kerbrat, Y., Majean-Dubois, S. (eds.), International Law faced with Environmental Challenges, Oxford, Hart Publishing, 2010.

82 Southern Pacific Properties (Middle East) Limited c. República Arabe de Egipto, Caso CIADI núm. ARB/84/3, Laudo del 20 de mayo de 1992, 3 ICSID Rep. 189 (1995) (“SPP c. Egipto”).

83 Convención para la Protección del. Patrimonio Mundial, Cultural y Natural, 16 de noviembre de 1972, 27 UST 37, 1037 UNTS 151. 
UNESCO con respecto a la Meseta de las Pirámides se volvieron obligatorias para el Demandado. A partir de esa fecha, las actividades del Demandante en la Meseta de las Pirámides habrían estado en conflicto con la Convención y por lo tanto, en violación del derecho internacional, y los beneficios que podrían haber resultado de esas actividades son, en consecuencia, no indemnizables. ${ }^{84}$

La clara postura que toma el tribunal a favor de la incorporación de consideraciones ambientales en el cálculo de la indemnización no permite determinar si dicha incorporación es fruto del carácter ambiental del interés protegido o simplemente de la conformidad de una situación con una obligación internacional relativa a otro campo de reglamentación. En otras palabras, el tribunal no aborda directamente la cuestión de la jerarquía de los intereses ambientales con respecto a los intereses pecuniarios de los inversionistas.

Ello nos lleva al segundo modo en que puede procederse a dicha valoración, a saber, con base en un análisis de la importancia relativa de los intereses que se desean proteger. A este respecto, nos parece útil distinguir conceptualmente entre cuatro categorías de medidas ambientales: i) medidas restrictivas en relación con sustancias/actividades directamente nocivas para la salud pública; ii) medidas restrictivas con relación a la protección del medio ambiente contra ciertas sustancias/actividades sin impacto directo sobre la salud pública; iii) medidas restrictivas tendientes a incrementar la eficiencia en la utilización de un recurso natural o de un derivado (agua, energía, tierras cultivables, etcétera); iv) medidas restrictivas tendientes a reducir el costo de la protección de un interés ambiental. Naturalmente, estas cuatro categorías sólo cubren

84 SPP c. Egipto, supra nota 82, párr. 191. (nuestra traducción del original en inglés). El tribunal señaló específicamente que su razonamiento se aplicaba al cálculo de la indemnización: "El siguiente factor invocado por el demandado para mitigar el monto de la indemnización en el presente caso es el hecho de que la reclasificación de la tierra en la Meseta de las Pirámides fue un acto lícito. Este factor, sin embargo, ha sido ya tenido en cuenta en la decisión del Tribunal de no conceder una indemnización basada en los beneficios que podrían haber correspondido a los demandantes después de la fecha en que las zonas de la meseta se registraron con el Comité del Patrimonio Mundial “, ibidem, párr. 250. (nuestra traducción del original en inglés) Véase el análisis de Liberti, L., "The Relevance of Non-Investment Treaty Obligations in Assessing Compensation”, en Dupuy, P.-M. et al., Human Rights in International Investment Law and Arbitration, Oxford University Press, 2009, p. 557. 
una parte de todas las medidas ambientales que podrían ser imaginadas; sin embargo, la mayoría de las medidas ambientales susceptibles de afectar los intereses de inversionistas extranjeros pueden ser ubicadas en una u otra de las categorías mencionadas. En dicho contexto, la teoría de los intereses protegidos consistiría en la introducción de una serie de valoraciones de principio, susceptibles de ser ajustadas a la luz de las circunstancias de cada caso.

Las medidas de la categoría (i) se verían cubiertas, en principio, por la doctrina de los poderes de policía, aun en presencia de compromisos específicos, ya que no puede esperarse razonablemente que un Estado renuncie a la protección de la salud de su población. Por ejemplo, cuando una medida ambiental es adoptada como resultado de una nueva comprensión científica de una determinada sustancia con el fin de proteger la salud humana, el ejercicio del poder regulatorio del Estado receptor no debería desencadenar su responsabilidad internacional. Dentro de este grupo podrían incluirse las restricciones adoptadas por distintos países para combatir la adicción al tabaco. Además de la prueba científica de que el tabaco es nocivo para la salud, existe un consenso cuasi universal de que los Estados deben adoptar medidas a fin de luchar contra la adicción al tabaco. ${ }^{85}$ Es importante tener presente que en el caso Chemtura c. Canada el tribunal consideró que, independientemente del hecho que no era función del tribunal determinar la exactitud de la ciencia en la que se basó un organismo regulatorio altamente especializado, no podía ignorar el hecho de que los efectos del lindano en la salud habían planteado serias preocupaciones a nivel internacional. ${ }^{86}$ Este análisis podría tener importantes efectos en la demanda que inició la compañía Phillip Morris contra Uruguay ante el CIADI en donde impugna las medidas adoptadas por el gobierno en la lucha contra el tabaco, como la que destina el 80\% del envase de cigarrillos a advertencias sanitarias o la que prohíbe por engañosas los tipos de marcas

85 Este consenso se ve reflejado en el hecho de que, al 11 de junio de 2010, 168 estados era partes en el Convenio Marco de la OMS para el Control del Tabaco. Véase http: / /www. who.int/fctc/signatories_parties/es/index.html.

86 Chemtura v. Canadá, supra nota 4, párrs. 134 y 135. 
como "light" o "mild". ${ }^{87}$ Inversamente, las medidas de la categoría (iv) no deberían operar, en principio, ni como justificación de la violación de un TBI ni como obstáculo a la indemnización de un inversionista. Por ejemplo, si el Estado receptor ha asumido compromisos específicos en relación con un inversionista en energías renovables y, algunos años más tarde, el Estado revoca su promesa para poder producir energía a menor costo (por ejemplo, utilizando carbón como combustible e incorporando un sistema de "carbon capture and storage" o "CCS" ${ }^{88}$ que, hipotéticamente, sería rentable), debería considerarse al Estado responsable y éste debería indemnizar al inversionista, todo ello quedando sujeto, naturalmente, a las circunstancias particulares del caso.

Entre estos dos extremos, las medidas de las categorías (ii) y (iii) persiguen un objetivo de protección del medio ambiente sin relación directa o inmediata (siempre existe una relación indirecta) con la salud pública o las condiciones básicas de la vida humana. Mientras que las medidas de la categoría (ii) buscan proteger el medio ambiente contra una amenaza inmediata (según los casos ciertas formas de contaminación, deforestación, control de las especies invasoras, etcétera), aquéllas de la categoría (iii) tienden a racionalizar el uso de un recurso (medidas de eficiencia en el uso del agua, de la energía o de la tierra cultivable) o, dicho de otro modo, a conciliar exigencias ambientales y económicas. Por dicha razón, el riesgo regulatorio debería ser soportado, en principio, tanto por el Estado como por el inversionista, la distribución siendo función de las circunstancias del caso y de criterios como aquéllos desarrollados en la jurisprudencia de la OMC sobre el artículo XX del GATT. Así por ejemplo, los tribunales podrían aplicar el criterio de que las medidas no deben aplicarse de manera que constituyan un medio de discriminación arbitraria o injustificable, o el concepto de la "necesidad" de la medida. De acuerdo con la jurisprudencia de la OMC, el evaluar si una medida, que no es indispensable puede ser "necesaria” implica un balance entre una serie de factores que incluyen: la importancia relativa

87 Véase “Tobacco Company Files Claim against Uruguay over Labelling Laws”, disponible en http: / / ictsd.org/i/news/bridgesweekly/71988/.

${ }^{88}$ La técnica de Carbon capture and storage (CCS) consiste en almacenar dióxido de carbono en forma subterránea y reutilizarla. Este proceso está en desarrollo y hasta el presente es energéticamente costoso. 
de los intereses o valores comunes que las medidas tienen por objeto proteger; la contribución de la medida a la consecución del objetivo, ${ }^{89} \mathrm{O}$ el carácter restrictivo y el impacto de la medida.

El empleo de la teoría de los intereses protegidos no debe (ni puede) ser rígido. Se trata simplemente de añadir cierta precisión conceptual al análisis de las interacciones entre dos ámbitos de actividad y de reglamentación en pleno desarrollo, como lo son la protección ambiental y aquélla de las inversiones extranjeras.

\section{CONCLUSIÓN}

A modo de conclusión, quisiéramos indicar brevemente cuáles son las tres conclusiones principales que se desprenden del análisis precedente.

El primer lugar, nuestro punto de partida es el auge de la reglamentación ambiental tanto a nivel internacional como interno. El impacto de las políticas ambientales sobre los operadores económicos ha sido estudiado, tradicionalmente, desde la perspectiva del derecho del comercio internacional. ${ }^{90}$ Desde esta perspectiva, las políticas ambientales son ante todo un factor de riesgo de litigio (para el Estado que las adopta),

89 A este respecto, en Brasil-Neumáticos, el órgano de apelación observó: “... Otro elemento decisivo del análisis de la necesidad de una medida con arreglo al apartado b) del artículo XX es su contribución al logro de su objetivo. Existe esa contribución cuando hay una relación auténtica de fines a medios entre el objetivo que se persigue y la medida en cuestión. Para que una medida pueda calificarse de necesaria no es preciso que sea indispensable. Sin embargo, su contribución al logro del objetivo debe ser importante, no meramente marginal ni insignificante, sobre todo si la medida de que se trata es tan restrictiva del comercio como una prohibición de las importaciones. Por lo tanto, la contribución de la medida debe confrontarse con el grado en que restringe el comercio, teniendo en cuenta la importancia de los intereses o los valores a que responde el objetivo perseguido con ella...”, Brasil - Medidas que afectan a las importaciones de neumáticos recauchutados AB-2007-4, Informe del Órgano de Apelación, WT/DS332/AB/R, 3 de diciembre de 2007, párr. 210.

90 Esty, D., Greening the GATT: Trade, Environment, and the Future, Washington, Institute for International Economics, 1994; Cameron, J. et al.(eds.), Trade and the Environment: The Search for Balance, London, Cameron May, 1994; Housman, R. et al., The Use of Trade Measures in Selected Multilateral Environmental Agreements, Geneva, UNEP, 1995; Charnovitz, S., "The WTO's Environmental Progress", (2007) 10(3) Journal of International Economic Law 685; Bodansky, D. y Lawrence, J. C., “Trade and Environment”, en Bethlehem, D. et al. (eds.), 
ya que pueden ser objeto de un litigio ante el órgano de resolución de disputas de la OMC, o un factor de riesgo comercial (para los Estados cuyas exportaciones se verían desfavorecidas por las restricciones impuestas por el Estado importador); sin embargo, las mismas políticas (o gran parte de ellas) también pueden crear otro tipo de riesgo, cuya importancia económica no debe ser subestimada, a saber, el riesgo de litigio en materia de inversiones, lo que nos lleva a nuestra segunda conclusión.

El manejo de los conflictos potenciales entre medidas ambientales e intereses de inversionistas extranjeros puede ser efectuado por medio de diversas formulaciones jurídicas de los poderes regulatorios del Estado receptor, como la doctrina de los poderes de policía, la doctrina del margen de apreciación y las cláusulas de emergencia pública y/o necesidad. En la práctica, el instrumento más importante es la doctrina de los poderes de policía, como lo demuestra la jurisprudencia en materia de inversiones; sin embargo, la jurisprudencia también sugiere la existencia de una excepción importante al ejercicio de dichos poderes, a saber, los casos de garantías o compromisos específicos asumidos por el Estado receptor ante el inversionista. El análisis doctrinal no parece haber superado este nivel, considerando que en dicho caso el Estado receptor debería ser responsable; sin embargo, aun en presencia de garantías o compromisos específicos, un análisis detenido de la jurisprudencia arbitral sugiere que existen ciertos criterios adicionales para distribuir el riesgo regulatorio en materia ambiental.

La tercera conclusión de nuestro análisis es que existen tres métodos de sopesar los diversos intereses en juego. El primero se concentra en el carácter razonable y/o legítimo de las expectativas del inversionista. Según las circunstancias del caso, podrá concluirse que, a pesar de las garantías o compromisos, el Estado receptor no ha infringido sus obligaciones internacionales en materia de protección de las inversiones extranjeras. El segundo método distribuye el riesgo regulatorio según el nivel de (falta de) diligencia tanto del inversionista como del Estado receptor. La distribución se opera no al nivel de la afectación de

Oxford Handbook of International Trade Law, Oxford, Oxford University Press, 2009, pp. 505 538. 
responsabilidad sino por medio del cálculo de la indemnización o, en otras palabras, de la contribución al daño. El tercer método, que hemos denominado la teoría de los intereses protegidos, propone una clave de distribución del riesgo regulatorio en función de la importancia de los intereses ambientales protegidos por diversas categorías de medidas. Estos tres métodos pueden ser empleados conjuntamente según el caso.

Queda por efectuar la ardua labor de identificar, para cada uno de los métodos propuestos, listas de criterios específicos que permitan medir el nivel de razonabilidad o de diligencia o, lo que sería aún más difícil, la jerarquía de los diversos valores que pueden encontrarse en juego. A este respecto, nuestro estudio se ha limitado a sugerir algunas posibilidades sin pretender cubrir la cuestión. De modo general, no se trata, bajo ningún concepto, de introducir rigidez en el delicado ejercicio de sopesar intereses de naturaleza diversa sino de explicitar ciertas regularidades, ciertos modos de proceder, que se encuentran implícitos en el razonamiento de la jurisprudencia arbitral, y cuya identificación permitirá a nuestro entender resolver serenamente los conflictos entre reglamentación ambiental y protección de las inversiones que se plantearán en el futuro. 